\title{
A Study on the Coupling Effect of School-Enterprise Cooperation in Vocational Education from Perspective of Economics*
}

\author{
Kun WANG \\ TianJin Vocational Institute, TianJin, China
}

\begin{abstract}
This article from the perspective of economics around the personnel training process costs and supply and demand sides of the difference, an analysis of the game between the vocational education and the industry enterprise, by defining the university-enterprise cooperation connotation of the coupling effect, system theory method, this paper expounds the practice and effectiveness of the government, industry enterprises and Vocational Colleges in the coupling effect of school enterprise cooperation,thus carried out profound cooperation,the establishment of long-term mechanism to provide a practical basis.
\end{abstract}

Keywords - economics perspective, vocational education, school-enterprise cooperation, coupling effect

\section{基于经济学视角的职业教育校企合作耦合效应分析}

\author{
王昆 \\ 天津职业大学, 天津, 中国
}

摘 要 本文从经济学角度围绕人才培养过程成本和供需双方差异, 在职业教育和行业企业之间形成的博竕进行了分析, 通过界 定校企合作耦合效应内涵, 采用系统理论方法, 阐述了政府、行业企业、职业院校在校企合作耦合效应中的对策和效能的发挥，从 而为政校企深度合作，建立长效机制提供了实践依据。

关键词 经济学视角, 职业教育, 校企合作, 耦合效应

\section{1. 引言}

国务院《关于加快发展现代职业教育的决定》中提到: “以服务发展为宗旨, 以促进就业为导向, 适应技术进步 和生产方式变革以及社会公共服务的需要, 培养数以亿计 的高素质劳动者和技术技能人才。” 校企合作不仅是职业教 育发展的重要战略, 也是助推经济结构调整、转型升级, 提供智力支持和人才保障的重要途径。现阶段职业教育校 企合作分为两种主要模式: 一种是以教育、科研技术人员 在合作中孵化科研成果, 创造经济效益的合作模式; 另一 种是以培养复合型、发展型、创新型技术技能人才为主要 目标, 实现教育育人的合作模式。两种模式的主要载体是 职业院校和行业企业, 在融合对接中形成增力, 相互作用、 彼此影响，推动和提升双方的发展。

*天津市哲学社会科学规划资助项目 (课题批准号: TJJX13)

\section{2. 从经济学角度进行校企合作耦合分析}

从职业教育校企科研合作模式来看, 已经形成了较为 成熟的成果转化利益分配机制, 合作成本主要通过利益双 驱动方式集中在双方的智力投资和技术回报方面, 没有更 多的冲突和矛盾; 从职业教育人才培养合作模式来看, 在 培养周期、内容、投入等多方面存在着模糊界限, 形成双 方隐性博亦，消弱校企合作，甚至产生负面影响。

\section{1 人才培养过程成本}

教育部在《国家教育事业发展第十二个五年规划》中 提出: “高等职业教育重点培养产业转型升级和企业技术 创新需要的发展型、复合型和创新型的技术技能人才。” 
职业教育定位于培养技术技能人才，这类人员大多分布在 高端制造业、服务业和新技术产业等职业领域技术操作岗 位, 这些岗位已经成功转型新技术新工艺, 对关键设备操 作和生产工艺流程要求比较高, 带来了岗前培训成本问题。 一方面, 职业院校是以通识教育和基本职业技能培训为主, 如数控、维修电工、PLC、服务技能等, 但具体到某一行业 企业, 如汽车模具行业、装配行业, 光伏行业等的设备和 工艺, 就需要企业依据生产工艺和设备情况具体完成相对 应的职业技能培训; 另一方面, 企业以生产利益最大化为 目标, 生产工艺和设备全方面围绕订单任务和项目运营服 务, 淘汰下的生产线也要用于转型升级或是进行资产置换, 对职业院校学生进行系统进行岗前培训的设备投入几乎为 零。因此, 校企合作进入到塩尤阶段: 如果企业将岗前培 训移入职业院校, 就需投入专项设备和资金, 而企业因追 求投入产出率而不愿意付出。

\section{2 供需双方隐性博亦}

职业院校和行业企业分别是技术技能人才供给和需求 方, 双方在人才的诉求上存在着较大差异。一方面, 职业 院校以人才培养最优化为目标, 强调技术、注重技能、关 注创新、兼顾人文、全面发展; 另一方面, 企业以人员投 入产出比最优化为目标, 忠于职守、信心百倍、技能成熟、 快速适应、高度执行、善于合作、追求卓越。一方是要培 养全面发展的合格人才, 另一方是要能快速上岗的具有职 业修养的成熟员工, 而学生成为一名岗位熟练工, 需要通 过在岗位实践中与具体工艺和机器设备, 以及生产过程接 触, 同时要和团队的技术交流才能提升认知和熟练操作。 这一过程还包括工作责任、安全要求、质量控制、提高效 率、行为规范等, 这些职业习惯的养成需要一个周期, 才 能培养出一名符合行业企业要求的熟练工。校企人才供求 差异造成了严重的结构性失业, 一方面有人没岗, 另一方 面有岗没人, 尤其是高技术设备、高等级自造也的技术技 能人才严重缺乏。因此, 在人才供求过程中, 形成了职业 院校与企业隐性博亦, 按照利已策略, 就会导致负和博亦, 合作失败。

综上所述, 职业教育校企合作折射出校企双方在人才 培养过程成本分推、供求过程人才诉求满足等方面存在着 相互作用, 相互影响, 相互制约的耦合现象, 解决好这个 问题是激发校企合作主体积极性和形成长效机制的关键, 而教育和产业又是社会分工的两个系统, 没有必然的约束 机制和制度建设, 是不可能达成合作的, 这恐怕也是困扰 我国职业教育校企合作向纵深开展的一个难题。

\section{3. 从心理学角度界定校企合作耦合效应内涵}

3.1 耦合效应的产生

耦合效应是指两个（或两个以上诸要素之间或诸系统 之间发生相关联系的）子系统通过中介环节的关联和相互 作用时, 既有作用与反作用方式, 又有吸引和排而形成更大 系统的现象。这种现象在复合材料力学中称为耦合效应。 应用在群体心理学中, 耦合效应也称互动效应, 联动效应, 人们把群体中两个或以上的个体通过相互作用而彼此影响 从而联合起来产生增力的现象, 称之为耦合效应。

\section{2 校企合作耦合效应内涵}

《国家中长期教育改革和发展规划纲要》(20102010）提出了 “要求建立健全政府主导、行业指导、企业 参与的办学体制。” 这里明确了职业教育校企合作应该是政 府、行业、企业和院校四方联动, 也同时确认了这四方主 体也是职业教育校企合作耦合效应产生的四个关联子系 统, 只有子系统都相互作用和影响, 才能激发能更大的能 量。

因此, 职业教育校企合作耦合效应内涵界定为, 政府 发挥统筹协调、法律保障、政策撞动作用; 行业发挥创新 机制、建立制度、典型推动作用; 企业发挥吸纳人才、培 训技能、资金支持作用; 学校发挥订单培养、技术服务、 资源共享作用; 四个子系统共同运作, 彼此影响、互惠互 利、相互促进, 进而产生增力, 就会形成校企合作的耦合 效应。

\section{4. 从系统学角度应用校企合作耦合效应}

\section{1 校企合作耦合效应的逻辑起点——职业院校}

职业院校是技术技能人才培养的逻辑起点。职业院校 承担着培养适应生产、管理和服务一线的高素质技术技能 人才的任务, 因此它是校企合作耦合效应产生和发挥效能 过程中最先运作的子系统。

\section{1.1 制度建设}

职业院校要做好校企合作顶层设计, 在人才培养、教 学改革、科研管理、人事分配、聘期考核、素质教育、校 园文化、实训项目、就业分配等诸多方面加强制度建设, 构建校企合作工作规范流程, 明确校企合作校、院两级管 理网络、任务分工、工作职责、工作目标和奖励资金, 做 到规范化、科学化、标准化。 


\section{1.2 组织机构建设}

职业院校积极探索集团化办学模式、以专业群为基础 的二级学院混合所有制、招工与招生相结合的现代学徒制, 建立董事会或理事会, 制定章程, 明确目标和任务, 最大 限度满足利益相关方的需求。设立校企合作专门机构, 配 置相应编制, 加强校企合作研究和管理, 深化校企合作深 度和广度发展。

\section{1.3 人才培养方案调整与专业建设}

职业院校依据区域经济结构调整和产业转型升级的需 要, 及时开展调研分析, 瞄准行业企业对技术技能人才需 求, 调整、修订、论证人才培养方案; 瞄准职业岗位要求, 开展 “教学做一体” 课程建设; 瞄准职业技能提升要求, 开发职业技能培训包建设。专业建设与教学改革更加贴近 行业要求。

\section{1.4 实训基地建设}

职业院校针对不同专业群人才培养任务, 开发建设具 有不同工学结合人才培养模式特色的实训基地项目, 形成 诸如以 “课证融合, 准技师”、“基于教学工厂理念” “旺 入淡出, 工学交替” “训赛结合、生产性” 等主题鲜明, 特色凸显的实训中心, 教学与生产相结合, 实训与比赛相 结合，仿真与实战相结合，成为引企入校的优势资源。

\section{1.5 “双教” 能力、“双师” 型师资建设}

职业院校采取请进来、送出去的方式开展师资培训, 通过到德国、澳大利亚、韩国等国家组团培训方式, 或是 邀请国际上知名专家到学校开展教育教学法培训等方式, 转换教师理念; 定期与地区职业技能鉴定中心合作开展教 师专业技能培训、鉴定开合工作，提升教师既教动脑又教 动手的 “双教” 能力; 定期开展教师到企业实习锻炼活动, 让教师在参与企业生产性活动中提升实践能力, 强化 “双 师型”师资建设。

\section{2 校企合作耦合效应的载体一一行业企业}

行业企业是技术技能人才发挥作用的载体。人才、技 术、设备是构成企业发展的三个重要因素, 其中人才是最 核心要素, 尤其实体性产业更是离不开技术技能人才的保 障和支撑。因此, 它是发挥校企合作耦合作用效能最大化 的子系统, 它的运行与否, 直接关联着校企合作的质量和 水平。

\subsection{1 制度建设}

做好顶层设计, 以行业为依托, 建立行业对接职业院 校专业群、服务企业技术服中心、素质教育基地、就业信 息平台等涉及订单培养、员工培训、技术服务、文化交流、
人员互派、素质提升等多方面的实施办法和具体举措, 有 的方面甚至上升为约定俗成和合作协议, 强化行业企业与 院校的对话机制和信息交流平台，完善利益驱动机制，推 动项目实施，达到目标实现。

\subsection{2 组织机构建设}

引校入企, 建立厂中校, 设立工作站, 有专门人员深 化校企合作，推动项目实施，完善项目管理，考核项目绩 效, 与院校的董事会或理事会、混合所有制管理机构等组 织部门形成对口管理模式, 定期召开沟通会, 交流信息, 结合双方需求开拓和深化合作项目。

\subsection{3 吸收学生顶岗实习与就业}

协调行业企业，及时发布技术技能人才需求，做好岗 位描述和规划, 引导不同阶段学生顶岗实习和就业, 结合 生产工艺、设备要求、安全管理开展技能培训, 提升素质 和技能水平，满足岗位要求，拓展职业发展空间。

\section{2.4 开展校企文化交流}

行业企业组织企业文化进校园，通过素质教育大讲堂、 企业文化宣传活动、学生走入企业参观、企业美丽一课堂 等活动, 让企业文化与校园文化进行交流和融合, 提升学 生对职业的认知度和对行业企业的认同感。

\section{3 校企合作耦合效应的保障一一政府}

技术技能人才培养需要投入成本，而校企双方在追求 成本一一效益性价比过程中形成隐性博亦，使得校企合作 很难以主动、广泛、深层次地联合起来产生增力, 最终导 致了 “一头热、一头冷” 的状态。解决这个难题的唯一途 径就是由政府来统筹协调,

4. 3.1 搭建平台, 创新合作机制

依托地区人社局、经济功能区等政府职能部门搭建合 作平台, 发挥统筹协调作用, 集聚行业企业资源与院校进 行优势互补、校企合作，建立科技园、科技成果转化基地、 技能人才培训基地等合作载体，创新合作机制和模式，拓 宽合作渠道和项目。

\section{3.2 制定实施办法, 建立组织机构}

地区政府职能部门结合区域产业结构特点和行业优 势, 释放政策红利, 推出促进校企合作的多项实施办法, 将推动校企合作的专门职能列入人社部门的工作任务, 在 人社部门与教育部门之间建立合署办公机构, 促进地区教 育与产业的政府职能融合，为推动工作简政放权，带来更 多便利。

\section{3.3 出台政策引导，提供资金支持}

出台政策毞动校企合作向纵深发展，促进地区经济发 
展, 加大资金支持力度, 在税收减免、培训福利、奖励资 助等方面真正实现优惠举措, 为校企合作项目得以开展和 顺利推动打下了坚实基础。

\section{4 校企合作耦合效应效能发挥}

\section{4.1 在人才培养模式上}

将行业企业用人标准融入职业教育人才的全过程, 形 成以 “人才共育、过程共管、成果共享、责任共担” 合作 机制。

\section{4.2 在员工培训模式上}

以行业企业技能比武为平台，建立 “技能培训一技能 大赛一技能晋级”三位一体的技术技能人才快速培养机制。

4. 4.3 在技术创新模式上

以技术创新和成果转化突破点, 项目孵化和创建创新 创业导师团队为渠道, 探索尝试科技服务企业之路, 形成 产学研用合作机制。

4. 4.4 在师资、技术人员交流模式上

打通教师到企业实习锻炼和聘任企业能工巧匠担任学 校兼聘教师的渠道, 探索建立 “双教” “双师” 型教师培养 机制。
4. 4.5 在素质教育模式上

通过建立素质教育拓展基地等形式, 以调研团队、志 愿者服务团队、社会实践团队为载体组织参与区内各类活

动, 形成院校在经济功能区等区域的素质教育拓展培养机 制。

\section{参考文献(References)}

[1] Peng Jiang. A study of coupling effect between vocational education and economic development. Education and Vocation, 2007 (27)

[2] Tang Yanping. A research on the influence of industrial structure adjustment on vocational education. Vocational \& Technical Education Forum, 2000 (12).

[3] Hong Xiao. Study on the generation of coupling effect of industry-university-research cooperation in higher vocational education . China Adult Education, 2011 (22).

[4] Zhang Lian, Liu Juan. The new opportunity, power and task of cooperative education. Vocational and Technical Education, $2012(33)$

[5] Chen Wei. A study on innovation of system and mechanism of school-enterprise cooperation from perspective of institutional economics. Education and Vocation, 2013 (15). 